\title{
Is Intralesional Treatment of Giant Cell Tumor of the Distal Radius Comparable to Resection With Respect to Local Control and Functional Outcome?
}

\author{
Robert W. Wysocki MD, Emily Soni MD, Walter W. Virkus MD, \\ Mark T. Scarborough MD, Sue E. Leurgans PhD, Steven Gitelis MD
}

Received: 21 April 2014/ Accepted: 6 November 2014/Published online: 4 December 2014

(C) The Association of Bone and Joint Surgeons ( 2014

\begin{abstract}
Background A giant cell tumor is a benign locally aggressive tumor commonly seen in the distal radius with reported recurrence rates higher than tumors at other sites. The dilemma for the treating surgeon is deciding whether intralesional treatment is adequate compared with resection of the primary tumor for oncologic and functional outcomes. More information would be helpful to guide shared decision-making.

Questions/purposes We asked: (1) How will validated functional scores, ROM, and strength differ between resection versus intralesional excision for a giant cell tumor
\end{abstract}

Each author certifies that he or she, or a member of his or her immediate family, has no funding or commercial associations (eg, consultancies, stock ownership, equity interest, patent/licensing arrangements, etc) that might pose a conflict of interest in connection with the submitted article.

All ICMJE Conflict of Interest Forms for authors and Clinical Orthopaedics and Related Research ${ }^{\circledR}$ editors and board members are on file with the publication and can be viewed on request.

Each author certifies that his or her institution approved the human protocol for this investigation, that all investigations were conducted in conformity with ethical principles of research, and that informed consent for participation in the study was obtained.

This work was performed at Rush University Medical Center, Midwest Orthopaedics at Rush, Chicago, IL, USA, and University of Florida Shands Orthopaedic and Sports Medicine Institute, Gainesville, FL, USA.

R. W. Wysocki ( $\square)$, S. Gitelis

Midwest Orthopaedics at Rush, Rush University Medical Center, 1611 West Harrison, Suite 300, Chicago, IL 60612, USA

e-mail: robertwysocki@me.com;

robert.wysocki@rushortho.com

E. Soni, M. T. Scarborough

University of Florida Shands Orthopaedic and Sports Medicine

Institute, Gainesville, FL, USA of the distal radius? (2) How will recurrence rate and reoperation differ between these types of treatments? (3) What are the complications resulting in reoperation after intralesional excision and resection procedures? (4) Is there a difference in functional outcome in treating a primary versus recurrent giant cell tumor with a resection arthrodesis?

Methods Between 1985 and 2008, 39 patients (39 wrists) were treated for primary giant cell tumor of the distal radius at two academic centers. Twenty patients underwent primary intralesional excision, typically in cases where bony architecture and cortical thickness were preserved, 15 underwent resection with radiocarpal arthrodesis, and four had resection with osteoarticular allograft. Resection regardless of reconstruction type was favored in cases with marked cortical expansion. A specific evaluation for purposes of the study with radiographs, ROM, grip strength, and pain and functional scores was performed at a minimum of 1 year for 21 patients (54\%) and an additional 11 patients $(28 \%)$ were available only by phone. We also assessed reoperations for recurrence and other complications via chart review.

Results With the numbers available, there were no differences in pain or functional scores or grip strength between groups; however, there was greater supination in the intralesional excision group $(p=0.037)$. Tumors recurred in six of 17 wrists after intralesional excision and

W. W. Virkus

Indiana University Health Physicians Orthopedics \& Sports Medicine, Rush University Medical Center, Indianapolis, IN, USA

S. E. Leurgans

Armour Academic Center, Rush University Medical Center, Chicago, IL, USA 
none of the 15 after en bloc resection $(p=0.030)$. There was no relationship between tumor grade and recurrence. There were 12 reoperations in eight of 17 patients in the intralesional excision group but only one of 11 patients $(\mathrm{p}=0.049)$ who underwent resection arthrodesis with distal radius allograft had a reoperation. There were no differences in functional scores whether resection arthrodesis was performed as the primary procedure or to treat recurrence after intralesional excision.

Conclusions Resection for giant cell tumor of the distal radius with distal radius allograft arthrodesis showed a lower recurrence rate, lower reoperation rate, and no apparent differences in functional outcome compared with joint salvage with intralesional excision. Because an arthrodesis for recurrence after intralesional procedures seems to function well, we believe that intralesional excision is reasonable to consider for initial treatment, but the patient should be informed about the relative benefits and risks of both options during the shared decision-making process. Because arthrodesis after recurrence functions similar to the initial resection and arthrodesis, an initial treatment with curettage remains a viable, and likely the standard, mode of treatment for most giant cell tumors of the distal radius unless there is extensive bone loss.

Level of Evidence Level III, therapeutic study.

\section{Introduction}

The distal radius is the third most common location for giant cell tumor of bone after the distal femur and proximal tibia, accounting for approximately $10 \%$ to $15 \%$ of cases $[10,27,29,30,40]$. Numerous authors have identified the distal radius as being particularly prone to recurrence $[2,8$, $10,13,16,21,30,36-39]$. The suspected contributing factors for this high rate of recurrence include the anatomic geometry of the distal radius, complexity of the distal radioulnar joint, and the paucity of surrounding muscle coupled with the close proximity of critical structures such as the median nerve, radial artery, and flexor and extensor tendons that make establishing wider margins challenging.

Although the oncologic outcome with en bloc resection is reported to be excellent $[2,10,16,18,27,29,36]$, this procedure sacrifices the joint, results in a major reconstruction, and functional outcomes are questionable. Intralesional excision preserves the joint but even if used in combination with surgical adjuvants has a reasonably high risk of local recurrence [18, 28, 30, 36]. Variables reported to influence local recurrence include the Campanacci grade $[2,18,22,27,30,34]$, pathologic fracture [27, 30, 40], tumor location $[2,13,16,27,36,39,40]$, type of adjuvant used $[2,7,10-12,16,17,25,27,30,32,35,36,38]$, and treatment of a primary versus a recurrent tumor [2, 27, 38].
En bloc resection has been reported to result in a lower local recurrence rate compared with an intralesional excision $[2,10,16,18,27,29,36]$.

Therefore we attempted to answer the following questions: (1) How will validated functional scores, ROM, and strength differ between resection procedures versus intralesional excision for giant cell tumors of the distal radius? (2) How will recurrence rate and reoperation differ between these types of treatments? (3) What are the complications resulting in reoperation after intralesional excision and resection procedures? (4) Is there a difference in functional outcome in treating a primary versus recurrent giant cell tumor with a resection arthrodesis?

\section{Patients and Methods}

\section{Study Design and Setting}

This was a retrospective comparative study of intralesional excision, resection arthrodesis, and resection with osteoarticular allograft for giant cell tumors of the distal radius at two tertiary orthopaedic oncology referral centers during a 25 -year period.

\section{Participants and Study Subjects}

After obtaining institutional review board approval, the musculoskeletal oncology databases from the two participating institutions were reviewed from 1985 to 2008, and all patients who underwent surgery for a primary giant cell tumor of the distal radius during the study period were identified with no exclusions. Thirty-nine such patients were identified with pathologic confirmation of a giant cell tumor at the time of surgery, however we did not personally review the pathology slides.

\section{Accounting for All Patients and Study Subjects}

At the time of data collection, one patient had died, leaving 38 patients from the initial cohort. Of those, six (16\%) were lost to followup and the remaining $32(84 \%)$ were available for followup at a median of 132 months and mean of 135 months (SD, 94; range, 14-309 months). Those available for followup included 17 of the original $20(85 \%)$ from the intralesional excision cohort, 11 of the original 15 (73\%) from the arthrodesis cohort, and four of four (100\%) from the osteoarticular allograft cohort. The mean duration of followup in the osteoarticular allograft group (245 months) was greater than that of the intralesional 
excision (100 months) and resection arthrodesis (153 months) groups ( $\mathrm{p}=0.0194)$.

\section{Description of Experiment, Treatment, or Surgery}

The primary surgery included intralesional excision in 20 patients $(51 \%)$, resection of the distal radius with radiocarpal arthrodesis in $15(38 \%)$, and resection of the distal radius with osteoarticular allograft without arthrodesis in four (10\%). Intralesional excision typically was recommended in lessadvanced cases with modest cortical thinning, well-maintained bony architecture, and no cortical disruption or pathologic fracture. Resection typically was recommended for patients who did not meet these criteria, with the choice of reconstruction (arthrodesis versus osteoarticular allograft) being at the surgeons' and patients' discretion. Numerous patients with advanced disease still chose to undergo intralesional excision in this setting. While there was variability in surgical strategy, most procedures were performed through a dorsal approach and the most common means of adjuvant therapy were burr exteriorization and polymethylmethacrylate cementation (Table 1). All patients undergoing osteoarticular allografting underwent a volar approach and plate fixation. We used the Campannaci grading system [9] to classify the preoperative grade on the preoperative images: a Grade 1 lesion has a well-defined margin and an intact cortex; a Grade 2 lesion has a relatively well-defined margin but no radiopaque rim, and the cortex is thinned and moderately expanded; and a Grade 3 lesion has indistinct borders and cortical destruction. A greater percentage of patients with Campanacci [9] Grade II disease underwent intralesional excision (13 of 15) and patients with Grade III disease underwent resection (13 of 24$)(\mathrm{p}=0.0017)$. Although there was some variation among centers and surgeons, patients typically would be followed up at 2 weeks, 6 weeks, 3 months, 6 months, and 1 year postoperatively with clinical visits and radiographs. Owing to the long-term nature of this study, all included patients for whom there was followup returned for a specific research visit or were contacted via phone at the designated time of final followup.

Variables, Outcome Measures, Data Sources, and Bias

Pain level was assessed with a VAS, oncologic functional outcome status was assessed with the Musculoskeletal Tumor Society (MSTS) score [14], and upper extremity function was assessed with the DASH questionnaire at final followup. Twenty-six patients had wrist radiographs performed and wrist arthrosis was assessed according to the grading scale of Knirk and Jupiter [20]. This system designates for Grade 1 as slight joint space narrowing, Grade 2 as
Table 1. Surgical details for intralesional excision and arthrodesis groups

\begin{tabular}{|c|c|}
\hline Details & $\begin{array}{l}\text { Number of } \\
\text { procedures }\end{array}$ \\
\hline Intralesional excision group & 20 \\
\hline \multicolumn{2}{|l|}{ Surgical approach } \\
\hline Dorsal & 14 \\
\hline Volar & 5 \\
\hline Combined dorsal/volar & 1 \\
\hline \multicolumn{2}{|l|}{ Adjuvant treatment } \\
\hline Burr exteriorization & 20 \\
\hline Phenol & 10 \\
\hline Electrocautery & 12 \\
\hline Argon beam & 4 \\
\hline Polymethylmethacrylate & 19 \\
\hline Cancellous allograft & 1 \\
\hline \multicolumn{2}{|l|}{ Internal fixation } \\
\hline Volar plate & 5 \\
\hline Dorsal plate & 3 \\
\hline No internal fixation & 12 \\
\hline Arthrodesis group & 15 \\
\hline \multicolumn{2}{|l|}{ Surgical approach } \\
\hline Dorsal & 14 \\
\hline Volar & 0 \\
\hline Combined dorsal/volar & 1 \\
\hline \multicolumn{2}{|l|}{ Reconstruction type } \\
\hline Nonvascularized fibular autograft & 6 \\
\hline Distal radius allograft & 3 \\
\hline Ulnar transposition & 3 \\
\hline Fibular allograft & 3 \\
\hline
\end{tabular}

marked narrowing with osteophyte formation, and Grade 3 as bone-on-bone narrowing with osteophyte and cyst formation. Twenty-two patients had physical examinations at final followup that included side-to-side comparisons of wrist and forearm ROM using standard goniometry and grip strength with standard Jamar dynamometry.

Oncologic outcome by surgical type (intralesional excision versus en bloc resection) was assessed according to the first treatment rendered. Functional outcome by treatment type was assessed according to the most recent treatment rendered (intralesional excision versus resection arthrodesis versus resection with osteoarticular allograft).

All chart reviews, clinical visits for research purposes, and phone surveys were performed by individuals other than the treating surgeons (RWW, ES).

Statistical Analysis and Study Size

Our statistical analysis included Fisher's exact tests to compare groups for dichotomous outcomes, Wilcoxon 

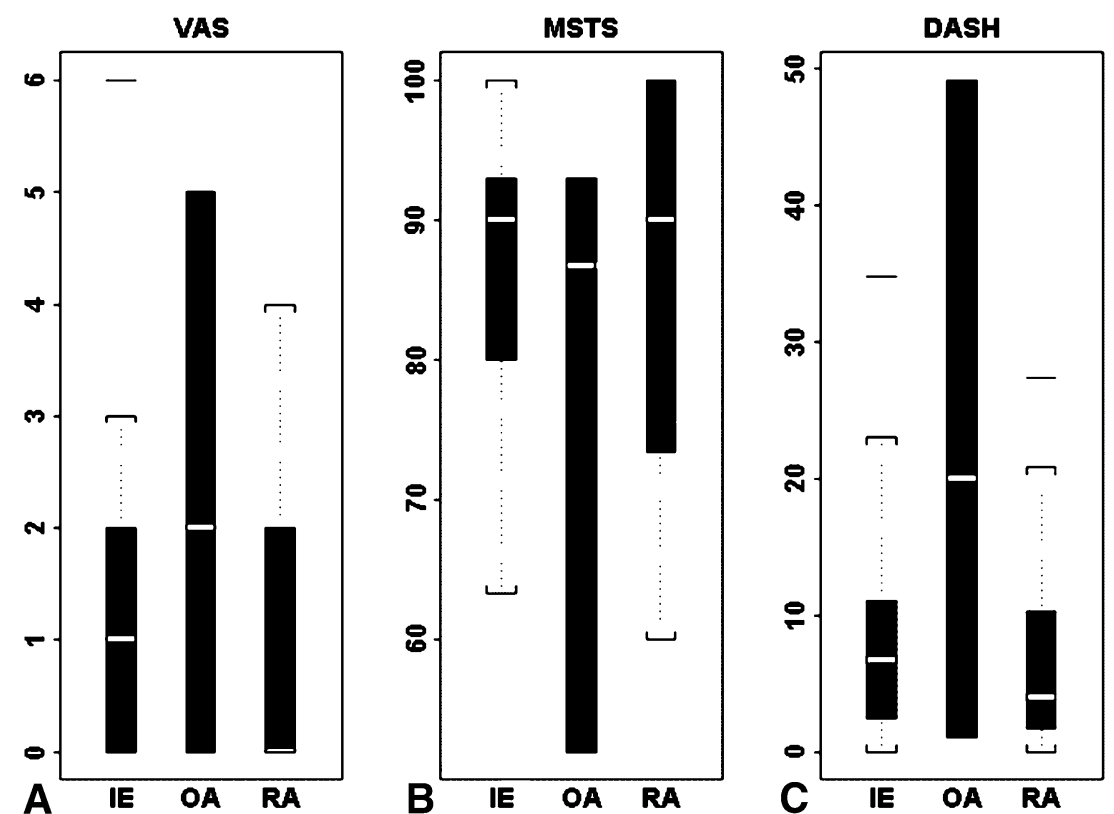

Fig. 1A-C (A) VAS, (B) MSTS, and (C) DASH functional scores based on final procedure type are shown. MSTS = Musculoskeletal Tumor Society, IE = Intralesional Excision, OA = Osteoarticular Allograft, RA = Resection Arthrodesis.

rank-sum tests to compare groups for continuous outcomes, Kaplan-Meier survival curves to display recurrence-free survival, and log rank tests to compare recurrence-free survival. Side-to-side comparisons were made in each group, and between-group comparisons were made by comparing the affected side as a percentage of the unaffected side for strength and ROM. Separate subgroup analyses were performed for differences in functional or oncologic outcome according to Campanacci grade and type of surgical treatment. Functional outcome also was compared based on whether the patient had a recurrence or whether an arthrodesis was performed as a primary or secondary procedure. For VAS pain scale with values from 0 to 10 , group sample sizes of 20 and 15 achieve $80.000 \%$ power to reject the null hypothesis of equal means when the population mean difference is $\mu 1$ to $\mu 2=0.0$ to $-1.5=1.5$ with a SD for both groups of 1.5 and a significance level (alpha) of 0.050 using a two-sided twosample equal-variance t-test.

\section{Demographics and Description of Study Population}

The mean age of the patients at the time of surgery was 34 years (SD, 14; range, 16-56 years), and there were 22 $(56 \%)$ males and $17(44 \%)$ females. Twenty-six lesions (67\%) were on the right and $13(33 \%)$ on the left. The dominant side was affected in $26(67 \%)$ patients. According to the staging system of Campanacci [9], no patients had Grade I disease, 15 (38\%) had Grade II disease, and 24
(62\%) had Grade III disease at the time of treatment. One (3\%) patient had pulmonary metastases at the time of diagnosis, 21 (54\%) had cortical disruption secondary to tumor growth with four (10\%) having extension into the radiocarpal joint, and nine (23\%) had pathologic fractures.

\section{Results}

Functional Scores, ROM, and Strength

With the numbers available, there were no important differences between the treatment groups in terms of validated functional scores, ROM, or strength. The intralesional excision, arthrodesis, and osteoarticular allograft groups, respectively, had mean DASH scores (7, 3, and 20), VAS scores (1, 0, and 2), and MSTS scores (90, 90, and 87) which showed no differences (Fig. 1). Final groupings included 12 patients with intralesional excision, 16 with arthrodesis, and four with osteoarticular allograft. The comparative subgroup analysis results among the three treatment cohorts based on final treatment for ROM and strength revealed no differences in grip strength, and the only applicable difference in ROM was decreased supination in the arthrodesis group $\left(73^{\circ}\right)$ compared with the intralesional excision group $\left(80^{\circ}\right)(\mathrm{p}=0.037)$ (Table 2). The patients who had intralesional excision also retained a flexion and extension arc that was absent in the patients who had arthrodesis, which could provide improved function. 
Table 2. Grip strength and ROM

\begin{tabular}{|c|c|c|c|c|}
\hline Physical examination parameter & Curettage & Arthrodesis & $\begin{array}{l}\text { Osteoarticular } \\
\text { allograft }\end{array}$ & $\begin{array}{l}\text { Comparison of unaffected } \\
\text { and affected sides, by procedure }\end{array}$ \\
\hline \multicolumn{5}{|l|}{ Grip strength (kg) } \\
\hline Affected & $\begin{array}{l}72.5 \\
\mathrm{SD}=27.45\end{array}$ & $\begin{array}{l}64.17 \\
\mathrm{SD}=27.28\end{array}$ & $\begin{array}{l}60.00 \\
S D=4.24\end{array}$ & \\
\hline Unaffected & $\begin{array}{l}74.25 \\
\mathrm{SD}=14.80\end{array}$ & $\begin{array}{l}82.67 \\
\mathrm{SD}=40.20\end{array}$ & $\begin{array}{l}86.50 \\
\mathrm{SD}=4.95\end{array}$ & \\
\hline $\begin{array}{l}\text { Difference between unaffected } \\
\text { and affected sides }\end{array}$ & $\begin{array}{l}1.75 \\
\mathrm{SD}=20.08 \\
\mathrm{p}=0.8728\end{array}$ & $\begin{array}{l}17.5 \\
\mathrm{SD}=13.98 \\
\mathrm{p}=0.0279\end{array}$ & $\begin{array}{l}26.5 \\
S D=9.19 \\
p=0.1531\end{array}$ & $\begin{array}{l}\mathrm{F}_{2,9}=0.1788 \\
\mathrm{p}=0.8392\end{array}$ \\
\hline \multicolumn{5}{|l|}{ Flexion } \\
\hline Affected & $\begin{array}{l}52.27 \\
\mathrm{SD}=15.87\end{array}$ & Not applicable & $\begin{array}{l}67.50 \\
\mathrm{SD}=17.68\end{array}$ & \\
\hline Unaffected & $\begin{array}{l}64.00 \\
\mathrm{SD}=16.97\end{array}$ & $\begin{array}{l}74.38 \\
\mathrm{SD}=18.02\end{array}$ & $\begin{array}{l}87.50 \\
\mathrm{SD}=3.54\end{array}$ & \\
\hline $\begin{array}{l}\text { Difference between unaffected } \\
\text { and affected sides }\end{array}$ & $\begin{array}{l}11.00 \\
\mathrm{SD}=13.29 \\
\mathrm{p}=0.0279\end{array}$ & Not applicable & $\begin{array}{l}20 \\
\mathrm{SD}=14.14 \\
\mathrm{p}=0.2952\end{array}$ & $\begin{array}{l}\mathrm{F}_{1,10}=0.745 \\
\mathrm{p}=0.4055\end{array}$ \\
\hline \multicolumn{5}{|l|}{ Extension } \\
\hline Affected & $\begin{array}{l}40.91 \\
\mathrm{SD}=12.21\end{array}$ & Not applicable & $\begin{array}{l}40.00 \\
\mathrm{SD}=7.07\end{array}$ & \\
\hline Unaffected & $\begin{array}{l}58.50 \\
\mathrm{SD}=16.17\end{array}$ & $\begin{array}{l}60.63 \\
\mathrm{SD}=8.21\end{array}$ & $\begin{array}{l}62.50 \\
\mathrm{SD}=3.54\end{array}$ & \\
\hline $\begin{array}{l}\text { Difference between unaffected } \\
\text { and affected sides }\end{array}$ & $\begin{array}{l}17.00 \\
\mathrm{SD}=18.73 \\
\mathrm{p}=0.0185\end{array}$ & Not applicable & $\begin{array}{l}22.50 \\
\mathrm{SD}=10.61 \\
\mathrm{p}=0.2048\end{array}$ & $\begin{array}{l}\mathrm{F}_{1,10}=0.154 \\
\mathrm{p}=0.7029\end{array}$ \\
\hline \multicolumn{5}{|l|}{ Ulnar deviation } \\
\hline Affected & $\begin{array}{l}15.00 \\
\mathrm{SD}=8.16\end{array}$ & Not applicable & $\begin{array}{l}17.50 \\
\mathrm{SD}=3.54\end{array}$ & \\
\hline Unaffected & $\begin{array}{l}21.11 \\
\mathrm{SD}=14.53\end{array}$ & $\begin{array}{l}36.88 \\
\mathrm{SD}=16.89\end{array}$ & $\begin{array}{l}25.00 \\
\mathrm{SD}=7.07\end{array}$ & \\
\hline $\begin{array}{l}\text { Difference between unaffected } \\
\text { and affected sides }\end{array}$ & $\begin{array}{l}5.56 \\
\mathrm{SD}=10.14 \\
\mathrm{p}=0.1388\end{array}$ & Not applicable & $\begin{array}{l}7.50 \\
S D=3.54 \\
p=0.2048\end{array}$ & $\begin{array}{l}\mathrm{F}_{1,10}=0.067 \\
\mathrm{p}=0.802\end{array}$ \\
\hline \multicolumn{5}{|l|}{ Radial deviation } \\
\hline Affected & $\begin{array}{l}10.00 \\
\mathrm{SD}=3.33\end{array}$ & Not applicable & $\begin{array}{l}25.00 \\
\mathrm{SD}=7.07\end{array}$ & \\
\hline Unaffected & $\begin{array}{l}11.11 \\
\mathrm{SD}=4.86\end{array}$ & $\begin{array}{l}20.00 \\
\mathrm{SD}=7.07\end{array}$ & $\begin{array}{l}25.00 \\
\mathrm{SD}=7.07\end{array}$ & \\
\hline $\begin{array}{l}\text { Difference between unaffected } \\
\text { and affected sides }\end{array}$ & $\begin{array}{l}1.11 \\
\mathrm{SD}=4.17 \\
\mathrm{p}=0.45\end{array}$ & Not applicable & $\begin{array}{l}15.00 \\
\mathrm{SD}=11.65 \\
\mathrm{p}=0.0083\end{array}$ & $\begin{array}{l}\mathrm{F}_{1,9}=0.13 \\
\mathrm{p}=0.7258\end{array}$ \\
\hline \multicolumn{5}{|l|}{ Pronation } \\
\hline Affected & $\begin{array}{l}0.63 \\
\mathrm{SD}=7.76\end{array}$ & $\begin{array}{l}84.29 \\
\mathrm{SD}=7.87\end{array}$ & $\begin{array}{l}75.00 \\
\mathrm{SD}=7.07\end{array}$ & \\
\hline Unaffected & $\begin{array}{l}84.38 \\
\mathrm{SD}=8.21\end{array}$ & $\begin{array}{l}90.0 \\
\mathrm{SD}=0\end{array}$ & $\begin{array}{l}75.00 \\
\mathrm{SD}=7.07\end{array}$ & \\
\hline $\begin{array}{l}\text { Difference between unaffected } \\
\text { and affected sides }\end{array}$ & $\begin{array}{l}3.75 \\
S D=4.43 \\
p=0.0479\end{array}$ & $\begin{array}{l}5.71 \\
S D=7.87 \\
p=0.1030\end{array}$ & $\begin{array}{l}0 \\
0, \\
*\end{array}$ & $\begin{array}{l}\mathrm{F}_{1,8}=1.309 \\
\mathrm{p}=0.2856\end{array}$ \\
\hline
\end{tabular}


Table 2. continued

\begin{tabular}{lllll}
\hline Physical examination parameter & Curettage & Arthrodesis & $\begin{array}{l}\text { Osteoarticular } \\
\text { allograft }\end{array}$ & $\begin{array}{l}\text { Comparison of unaffected } \\
\text { and affected sides, by procedure }\end{array}$ \\
\hline Supination & & & \\
Affected & 80.00 & 72.86 & 52.50, \\
& $\mathrm{SD}=7.56$ & $\mathrm{SD}=12.20$ & $\mathrm{SD}=10.61$ & 72.50, \\
Unaffected & 86.25, & 90.00, & $\mathrm{SD}=10.61$ & $\mathrm{~F}_{1,8}=6.245$ \\
& $\mathrm{SD}=5.18$ & $\mathrm{SD}=0$ & 20, & $\mathrm{p}=0.037$ \\
Difference between unaffected & 6.25, & 17.14, & 0, & $*$ \\
\hline and affected sides & $\mathrm{SD}=7.44$ & $\mathrm{SD}=12.20$, & $\mathrm{p}$ \\
& $\mathrm{p}=0.0492$ & $\mathrm{p}=0.0099$ & $*$ & \\
\hline
\end{tabular}

* No $\mathrm{p}$ value; for pronation and supination, the number of patients with osteoarthritis was too small to provide a statistical comparison of side-toside differences within group.

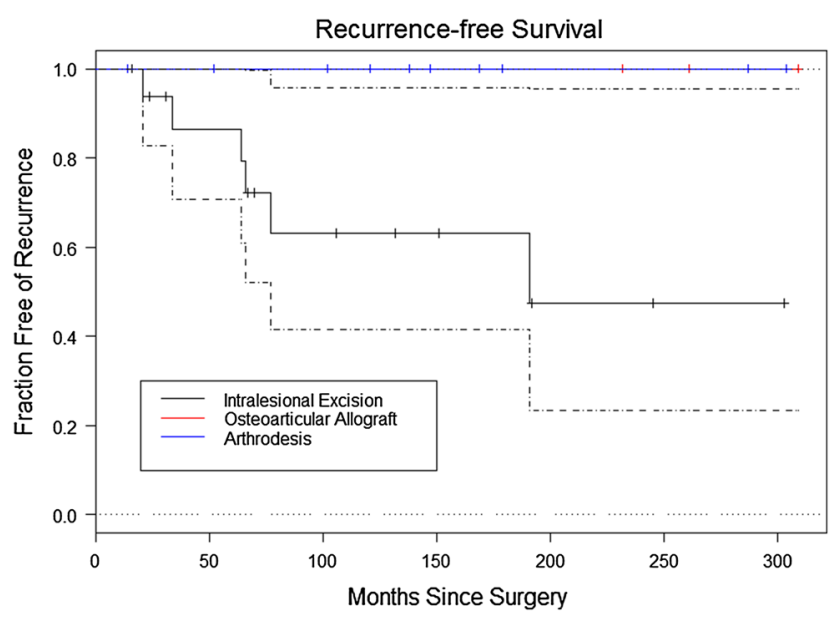

Fig. 2 A Kaplan-Meier curve with CIs (dashed lines) shows survival with reoperation specifically for recurrence as an endpoint, based on the type of index procedure.

\section{Recurrence Rate and Reoperation}

There were more tumor recurrences in the intralesional excision cohort than in the resection arthrodesis or osteoarticular allograft cohorts (six of 17 versus 0 of 11 and 0 of four, respectively; $\log$ rank tests chi-square $=7.016$, $\mathrm{p}=0.03$ ). There was no difference in recurrence between the two centers. The mean time to recurrence was 19 months (range, 8-47 months) (Fig. 2). Of the six tumor recurrences, three were Campanacci Grade II and three were Grade III at the time of initial treatment. There was no relationship between the likelihood of recurrence and Campanacci grade, pathologic fracture, or penetration through the cortex. Three patients underwent repeat intralesional excision and three underwent resection with allograft arthrodesis as their subsequent procedure for recurrence. Of the three patients undergoing repeat intralesional excision, two remained disease-free at the time of final followup, whereas one had a second recurrence develop 10 months postoperatively and was treated with a resection and allograft arthrodesis after this second recurrence. This patient was disease-free at final followup. Of the three patients with initial recurrences treated with resection and allograft arthrodesis, two remained diseasefree at final followup, whereas one had tumor recurrence at the second metacarpal base at 36 months that was treated with intralesional excision, and the patient was disease-free at final followup.

\section{Other Complications After Intralesional Curettage and Resection}

With the numbers available there were no differences in the frequency of reoperation among the groups. In the total cohort there were 16 reoperations in 12 patients (38\%), including 12 operations in eight patients $(47 \%)$ of the intralesional excision group, four operations in three patients $(27 \%)$ in the arthrodesis group, and zero patients $(0 \%)$ in the osteoarticular allograft group (Fig. 3). Eight reoperations were performed for recurrence and eight for reasons other than recurrence (Table 3). In the intralesional excision group, five patients (29\%) underwent eventual allograft arthrodesis for either recurrence (four) or fracture (one). Of the 11 patients who underwent distal radius resection with reconstruction specifically using distal radius allograft either as their primary procedure or as a repeat operation after intralesional excision, the union rate was $100 \%$ with only one reoperation (9\%), which was the distal ulna resection in a patient who had an arthrodesis after a failed intralesional excision. Nonunion occurred in one of the six (17\%) patients with fibular autograft fusion, one of the three $(33 \%)$ with ulnar transposition and fusion, and one of the three (33\%) with fibular allograft fusion. When the reoperation rate after reconstruction with distal 


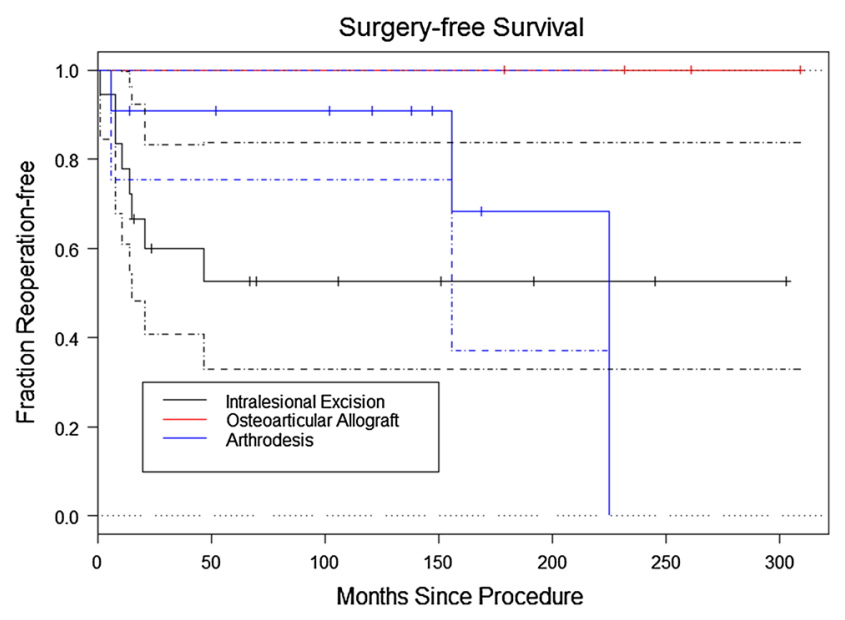

Fig. 3 A Kaplan-Meier curve with CIs (dashed lines) shows survival with a first reoperation for any reason as an endpoint, based on the type of index procedure.

Table 3. Reoperations by group

\begin{tabular}{ll}
\hline Reoperation & $\begin{array}{c}\text { Number of } \\
\text { procedures }\end{array}$ \\
\hline $\begin{array}{l}\text { Intralesional excision group } \\
\text { Repeat intralesional excision }\end{array}$ & 3 \\
$\begin{array}{l}\text { Resection with distal radius allograft arthrodesis for } \\
\text { first recurrence }\end{array}$ & 3 \\
$\begin{array}{l}\text { Resection with distal radius allograft arthrodesis to treat } \\
\text { second recurrence }\end{array}$ & 1 \\
$\begin{array}{l}\text { Intralesional excision of spread to } 2^{\text {nd }} \text { metacarpal base } \\
\text { in a patient who had arthrodesis after failed }\end{array}$ & 1 \\
intralesional excision & \\
$\begin{array}{l}\text { Distal ulna resection for ulnar-sided wrist pain in a } \\
\text { patient who had arthrodesis after failed intralesional }\end{array}$ & 1 \\
excision & \\
$\begin{array}{l}\text { Resection with distal radius allograft arthrodesis to treat } \\
\text { fracture } 1 \text { month after intralesional excision }\end{array}$ & 1 \\
$\begin{array}{l}\text { Second dorsal compartment tenosynovectomy with } \\
\text { bone spur excision }\end{array}$ & 1 \\
Negative biopsy for possible recurrence & 1 \\
$\begin{array}{l}\text { Arthrodesis group } \\
\text { Revision fixation with bone grafting for failed } \\
\text { arthrodesis }\end{array}$ & 3 \\
$\begin{array}{l}\text { Resection of fibular allograft for second nonunion, } \\
\text { converted to ulnar transposition }\end{array}$ & 1 \\
\hline
\end{tabular}

radius allograft was compared with the rate of intralesional excision, a higher reoperation rate was seen with intralesional excision (eight reoperations in 17 patients undergoing intralesional excision [47\%] versus one in 11 patients undergoing distal radius allograft arthrodesis [9\%]; $\mathrm{p}=0.049$ ). We theorize the success of reconstruction using distal radius allograft potentially is attributable to a better overall surface area match between the native radius and a radius allograft than a narrower bone such as the fibula. The surface area also allows the surgeon to make a step cut in the radius to allow for further increased surface area and some intrinsic stability. Review of radiographs at final followup revealed no patients with nonunion, hardware complications, or adjacent arthritis in the arthrodesis cohort. Of the patients who had osteoarticular allograft, radiographs were available at final followup for two, both of whom had Grade II arthrosis [20]. Of the 11 patients with available radiographs in the intralesional excision cohort who did not have conversion to arthrodesis at the time of final followup, five (45\%) had radiographic signs of radiocarpal arthrosis, which was Grade I in two patients and Grade II in three patients. All five patients had Campanacci Grade II disease before surgery. There were no differences in the DASH, VAS, or MSTS scores between patients in the intralesional excision group with and without radiographic arthritis, respectively.

\section{Functional Outcomes: Primary Versus Recurrent Giant Cell Tumor Treated by Resection Arthrodesis}

There were no differences in DASH, VAS, or MSTS scores between whether an arthrodesis was done as the initial primary treatment $(n=11)$ or as a secondary procedure $(\mathrm{n}=5)$ to treat a failed intralesional excision.

\section{Discussion}

A giant cell tumor of the distal radius is a locally aggressive, periarticular, benign neoplastic process with particularly high recurrence rates at the wrist compared with other sites [2,15], and the wrist is a joint where arthrodesis can function well in comparison to some major joints. These considerations raise the questions we set out to answer regarding how recurrence rates, functional outcomes, and complication and reoperation profiles differ between treatment groups, and whether there is a difference between undergoing an arthrodesis as the index procedure versus as treatment for a recurrence. Our goal was to provide results that can help counsel patients on balancing recurrence risk and reoperation rates versus functional loss for the principal treatment options. To our knowledge, this is the largest series of functional and oncologic outcomes of giant cell tumors of the distal radius and with the longest median duration of followup.

This study had numerous limitations. It is retrospective and has a small sample size, but these are not uncommon for studies of patients with musculoskeletal tumors. With larger numbers, some of the expected differences in 
function between arthrodesis and mobile wrists might have become apparent. This is especially true for osteoarticular allografts of the distal radius, as in that group, there were only four patients. Conversely, selection bias may be present as patients with lower-grade disease were more likely to be treated with intralesional excision than those with higher-grade disease. Such bias could set up the resection group for worse oncologic and functional outcomes than the intralesional excision group. This selection bias is somewhat unavoidable as the current standard of care is for resection to be performed preferentially for more severe cases. There was also a lack of uniformity in the way the surgical procedures were performed, especially the different types of arthrodesis procedures and to a lesser degree the adjuvants used during intralesional excision. Six patients were lost to followup, and some patients available for followup did not have radiographs or physical examination data available, which introduces potential transfer bias to our study. We also did not have sufficient reconstruction types such as autograft fibula grafts used either for arthrodesis or osteoarticular reconstructions nor did we look at vascularized fibular grafts, so our ability to state that arthrodesis is a superior reconstruction method is limited. We can show only that the results in our patients provided them with reasonable function.

With the number of patients analyzed, we could not detect a difference in the functional scores of the arthodesis group compared with those of the intralesional excision and osteoarticular allograft groups. However, the expected loss of wrist motion after arthrodesis did not seem to adversely affect function compared with the other groups. The patients undergoing intralesional excision did retain increased supination compared with the arthrodesis cohort, and the expected retained flexion and extension of the wrist which was absent in the arthrodesis cohort. Few studies have made direct comparisons in functional outcomes between treatment groups [13, 19, 33, 36]. Kang et al. [19], in a series of 15 patients with Grade III tumors at a mean followup of 5 years, found greater grip strength $(83 \%$ versus 58\% of contralateral side) and improved VAS scores (1.2 versus 3 ) in nine patients treated with intralesional excision compared with six treated with arthrodesis. Cheng et al. [13] compared six patients treated with intralesional excision and six treated with osteoarticular allograft. At a mean followup of 6 years, the patients who had allograft retained $69 \%$ ROM and $70 \%$ grip strength compared with the contralateral side, whereas no measureable differences were seen in the intralesional group. Excellent results were seen in six of six in the intralesional group and four of six in the allograft group. Puloski et al. [33] compared intralesional excision and resection arthrodesis in 33 patients with aggressive distal radius tumors ( 25 giant cell tumors, eight sarcomas). They found poorer results by
DASH (20 versus 8) and MSTS (27 versus 31$)$ in the arthrodesis group compared with the intralesional excision group, respectively, and no difference in VAS scores. The arthrodesis group retained more strength in comparison to the unaffected side than the intralesional excision group (75\% versus 53\%). Radiographic arthritis was evident in $63 \%$ of patients who underwent intralesional excision. Sheth et al. [36] found comparable MSTS scores and grip strength when comparing intralesional excision and resection arthrodesis, respectively, for giant cell tumor of the distal radius in 26 patients. Some favorable functional results also have been reported for osteoarticular allograft reconstruction using proximal fibular autograft, however none were performed in our patients and there are concerns with high complication rates [1, 3, 6, 23, 24, 26, 31].

Our results indicate a higher recurrence rate for patients treated with intralesional excision (35\%) versus those treated with resection $(0 \%)$. We also found a higher reoperation rate for intralesional excision (47\%), specifically when compared with resection arthrodesis or osteoarticular allograft specifically using distal radius allograft $(9 \%)$. The difference in recurrence is between intralesional excision and en bloc resection and is independent of the type of reconstruction used after resection. All of the patients who had intralesional excision eventually were disease free, and two of the six patients with recurrences maintained their distal radial joint. Many large series of intralesional excision for giant cell tumors in all locations reported recurrences between $10 \%$ and $25 \%$ [2, 8, $10,11,16,19,30,35,38,39]$. The distal radius is somewhat unique among locations for a giant cell tumor in that it has shown one of the highest rates of recurrence with intralesional surgery. McGough et al. [28] reported 30\% recurrence in 33 patients, Harness and Mankin [18] reported $42 \%$ recurrence in 26 patients, Sheth et al. [36] reported $25 \%$ recurrence in 12 patients, and O'Donnell et al. [30] reported 50\% recurrence in 10 patients. Conversely, en bloc resection of the distal radius with either arthrodesis or osteoarticular allograft has reported low recurrence rates of $0 \%[1,4,5,13,19,31,36,39]$, with few studies showing recurrence in greater than $25 \%$ [26, 29].

We found that seven patients underwent eight operative procedures for reasons other than recurrence in the three treatment types, including four of 15 in the intralesional excision and four of 11 in the arthrodesis groups. Harness and Mankin [18] reported reoperations for reasons other than recurrence in nine of 20 patients who had intralesional excision. They did not break down reoperation rate for arthrodesis versus osteoarticular allograft. Sheth et al. [36] reported reoperations in four of 18 patients after intralesional excision for reasons other than recurrence, and four of 10 patients after arthrodesis in all cases for graft failure. Vander Griend and Funderburk [39] reported 
reoperation for reasons other than recurrence in five of 14 patients after arthrodesis for giant cell tumor, four of those being for graft failure or fracture. Our reoperation rates for intralesional excision and resection arthrodesis appear similar to those in several studies [18, 36, 39]. Although osteoarticular allograft for tumor does preserve wrist motion, concerns for distal radioulnar joint instability and other complications have been reported [6, 13, 21, 26, 39]. Bianchi et al. [6] found distal radioulnar joint instability in eight of 12 patients and all had cyst formation and joint space narrowing, but only one was painful. Kocher et al. [21] reported on 24 patients, of whom eight needed revision of the allograft. Seven had conversion of the allograft to arthrodesis, and one underwent an amputation. Of the 16 patients in whom the graft survived, $81 \%$ had pain. Cheng et al. [13], Vander Griend and Funderburk [39], and Maruthainar et al. [26] reported high rates of complications such as radiocarpal and distal radioulnar joint arthrosis or instability after osteoarticular allograft. Despite the favorable results with osteoarticular allograft in our series, we had few patients and we share the concerns that these authors have reported. If we had more osteoarticular allografts we might have had similar findings, therefore we do not favor this as the preferred treatment for giant cell tumors of the distal radius. Despite decreased supination in the arthodesis cohort, our data support no functional detriment in functional scores with arthrodesis compared with intralesional excision (Fig. 1). The relatively high rates of radiographic arthritis in our patients and as reported by others [18, 30, 36, 39] are of unclear clinical importance.

With the numbers available, we detected no differences in pain scores or functional outcome measures whether an arthrodesis was done as an index or secondary procedure. To our knowledge, this has not been formally addressed in the literature, but we believe it is relevant in trying to counsel patients regarding whether the increased recurrence and reoperation rates of intralesional excision place them at risk of a poorer outcome if they have an arthrodesis later versus if they had an arthrodesis as their index procedure.

Our results should guide the treating surgeon to better shared decision-making with a patient who has a distal radial giant cell tumor of bone. We believe, based on this study, that primary treatment with intralesional excision is reasonable, because patients who had a salvage arthrodesis after a recurrence after an intralesional excision had no worse function than patients who underwent primary arthrodesis. Therefore, if a patient is willing to accept the higher recurrence and reoperation rates of an intralesional excision to preserve wrist ROM, it appears that the final outcome if they undergo arthrodesis in the future may be no different. Given the lower recurrence rates, lower reoperation rate, and functional scores that appear equivalent to those for intralesional excision, we encourage consideration of resection and allograft arthrodesis for primary treatment of giant cell tumors of the distal radius in patients with advanced Campanacci stage disease despite the decreased supination detected in our cohort. Because we did not study other reconstructive methods, we cannot state that arthrodesis is superior to other reconstruction options. Although patients with osteoarticular allograft in this series had no reoperations, our numbers are too small to comment definitively, but high complication rates have been reported in other series [6, 13, 21, 26, 39]. We now favor distal radius allograft arthrodesis because it has low reoperation and nonunion rates using this technique in our series compared with the overall reoperation rate in the series as a whole. Until further multicenter studies that include larger numbers of patients are completed, our results should be considered preliminary.

\section{References}

1. Asavamongkolkul A, Waikakul S, Phimolsarnti R, Kiatisevi P. Functional outcome following excision of a tumour and reconstruction of the distal radius. Int Orthop. 2009;33:203-209.

2. Arbeitsgemeinschaft Knochentumoren, Becker WT, Dohle J, Bernd L, Braun A, Cserhati M, Enderle A, Hovy L, Matejovsky Z, Szendroi M, Trieb K, Tunn PU. Local recurrence of giant cell tumor of bone after intralesional treatment with and without adjuvant therapy. J Bone Joint Surg Am. 2008;90:1060-1067.

3. Bassiony AA. Giant cell tumour of the distal radius: wide resection and reconstruction by non-vascularised proximal fibular autograft. Ann Acad Med Singapore. 2009;38:900-904.

4. Bhagat S, Bansal M, Jandhyala R, Sharma H, Amin P, Pandit JP. Wide excision and ulno-carpal arthrodesis for primary aggressive and recurrent giant cell tumours. Int Orthop. 2008;32:741-745.

5. Bhan S, Biyani A. Ulnar translocation after excision of giant cell tumour of distal radius. J Hand Surg Br. 1990;15:496-500.

6. Bianchi G, Donati D, Staals EL, Mercuri M. Osteoarticular allograft reconstruction of the distal radius after bone tumour resection. J Hand Surg Br. 2005;30:369-373.

7. Bini SA, Gill K, Johnston JO. Giant cell tumor of bone: curettage and cement reconstruction. Clin Orthop Relat Res. 1995;321: 245-250.

8. Blackley HR, Wunder JS, Davis AM, White LM, Kandel R, Bell RS. Treatment of giant-cell tumors of long bones with curettage and bone-grafting. J Bone Joint Surg Am. 1999;81:811-820.

9. Campanacci M. Giant-cell tumor and chondrosarcomas: grading, treatment and results (studies of 209 and 131 cases). Recent Results Cancer Res. 1976;54:257-261.

10. Campanacci M, Baldini N, Boriani S, Sudanese A. Giant-cell tumor of bone. J Bone Joint Surg Am. 1987;69:106-114.

11. Capanna R, Fabbri N, Bettelli G. Curettage of giant cell tumor of bone: the effect of surgical technique and adjuvants on local recurrence rate. Chir Organi Mov. 1990;75(1 suppl):206.

12. Capanna R, Sudanese A, Baldini N, Campanacci M. Phenol as an adjuvant in the control of local recurrence of benign neoplasms of bone treated by curettage. Ital J Orthop Traumatol. 1985;11: 381-388.

13. Cheng CY, Shih HN, Hsu KY, Hsu RW. Treatment of giant cell tumor of the distal radius. Clin Orthop Relat Res. 2001; $383 ; 221-228$. 
14. Enneking WF, Dunham W, Gebhardt MC, Malawar M, Pritchard DJ. A system for the functional evaluation of reconstructive procedures after surgical treatment of tumors of the musculoskeletal system. Clin Orthop Relat Res. 1993;286:241-246.

15. Errani C, Ruggieri P, Asenzio MA, Toscano A, Colangeli S, Rimondi E, Rossi G, Longhi A, Mercuri M. Giant cell tumor of the extremity: a review of 349 cases from a single institution. Cancer Treat Rev. 2010;36:1-7.

16. Gitelis S, Mallin BA, Piasecki P, Turner F. Intralesional excision compared with en bloc resection for giant-cell tumors of bone. J Bone Joint Surg Am. 1993;75:1648-1655.

17. Goldenberg RR, Campbell CJ, Bonfiglio M. Giant-cell tumor of bone: an analysis of two hundred and eighteen cases. J Bone Joint Surg Am. 1970;52:619-664.

18. Harness NG, Mankin HJ. Giant-cell tumor of the distal forearm. J Hand Surg Am. 2004;29:188-193.

19. Kang L, Manoso MW, Boland PJ, Healey JH, Athanasian EA. Features of grade 3 giant cell tumors of the distal radius associated with successful intralesional treatment. J Hand Surg Am. 2010;35:1850-1857.

20. Knirk JL, Jupiter JB. Intra-articular fractures of the distal end of the radius in young adults. J Bone Joint Surg Am. 1986;68: 647-659.

21. Kocher MS, Gebhardt MC, Mankin HJ. Reconstruction of the distal aspect of the radius with use of an osteoarticular allograft after excision of a skeletal tumor. J Bone Joint Surg Am. 1998;80:407-419.

22. Lackman RD, Hosalkar HS, Ogilvie CM, Torbert JT, Fox EJ. Intralesional curettage for grades II and III giant cell tumors of bone. Clin Orthop Relat Res. 2005;438:123-127.

23. Lackman RD, McDonald DJ, Beckenbaugh RD, Sim FH. Fibular reconstruction for giant cell tumor of the distal radius. Clin Orthop Relat Res. 1987;218:232-238.

24. Mack GR, Lichtman DM, MacDonald RI. Fibular autografts for distal defects of the radius. J Hand Surg Am. 1979;4:576-583.

25. Marcove RC, Weis LD, Vaghaiwalla MR, Pearson R. Cryosurgery in the treatment of giant cell tumors of bone: a report of 52 consecutive cases. Clin Orthop Relat Res. 1978;134:275-289.

26. Maruthainar N, Zambakidis C, Harper G, Calder D, Cannon SR, Briggs TW. Functional outcome following excision of tumours of the distal radius and reconstruction by autologous non-vascularized osteoarticular fibula grafting. J Hand Surg Br. 2002;27: 171-174.
27. McDonald DJ, Sim FH, McLeod RA, Dahlin DC. Giant-cell tumor of bone. J Bone Joint Surg Am. 1986;68:235-242.

28. McGough RL, Rutledge J, Lewis VO, Lin PP, Yasko AW. Impact severity of local recurrence in giant cell tumor of bone. Clin Orthop Relat Res. 2005;438:116-122.

29. Murray JA, Schlafly B. Giant-cell tumors in the distal end of the radius: treatment by resection and fibular autograft interpositional arthrodesis. J Bone Joint Surg Am. 1986;68:687-694.

30. O'Donnell RJ, Springfield DS, Motwani HK, Ready JE, Gebhardt MC, Mankin HJ. Recurrence of giant-cell tumors of the long bones after curettage and packing with cement. J Bone Joint Surg Am. 1994;76:1827-1833.

31. Ono H, Yajima H, Mizumoto S, Miyauchi Y, Mii Y, Tamai S. Vascularized fibular graft for reconstruction of the wrist after excision of giant cell tumor. Plast Reconstr Surg. 1997;99:1086-1093.

32. Persson BM, Ekelund L, Lovdahl R, Gunterberg B. Favourable results of acrylic cementation for giant cell tumors. Acta Orthop Scand. 1984;55:209-214.

33. Puloski SK, Griffin A, Ferguson PC, Bell RS, Wunder JS. Functional outcomes after treatment of aggressive tumors in the distal radius. Clin Orthop Relat Res. 2007;459:154-160.

34. Rock M. Curettage of giant cell tumor of bone: factors influencing local recurrences and metastasis. Chir Organi Mov. 1990;75(1 suppl):204-205.

35. Saiz P, Virkus W, Piasecki P, Templeton A, Shott S, Gitelis S. Results of giant cell tumor of bone treated with intralesional excision. Clin Orthop Relat Res. 2004;424:221-226.

36. Sheth DS, Healey JH, Sobel M, Lane JM, Marcove RC. Giant cell tumor of the distal radius. J Hand Surg Am. 1995;20:432-440.

37. Smith RJ, Mankin HJ. Allograft replacement of distal radius for giant cell tumor. J Hand Surg Am. 1977;2:299-308.

38. Turcotte RE, Wunder JS, Isler MH, Bell RS, Schachar N, Masri BA, Moreau G, Davis AM; Canadian Sarcoma Group. Giant cell tumor of long bone: a Canadian Sarcoma Group study. Clin Orthop Relat Res. 2002;397:248-258.

39. Vander Griend RA, Funderburk $\mathrm{CH}$. The treatment of giant-cell tumors of the distal part of the radius. J Bone Joint Surg Am. 1993;75:899-908.

40. Vult von Steyern F, Bauer HC, Trovik C, Kivioja A, Bergh P, Holmberg Jorgensen P, Folleras G, Rydholm A; Scandanavian Study Group. Treatment of local recurrences of giant cell tumour in long bones after curettage and cementing: a Scandinavian Sarcoma Group study. J Bone Joint Surg Br. 2006;88:531-535. 